\title{
Genetic effects for maize traits in acid and non-acid soils
}

\author{
Juan C. Pérez Velásquez ${ }^{1}$, Cláudio Lopes de Souza Jr. ${ }^{2}$, Luis A. Narro ${ }^{3}$, Shivaji Pandey ${ }^{4}$ \\ and Carlos De León ${ }^{4}$ \\ ${ }^{1}$ International Center for Tropical Agriculture, Cali, Colombia. \\ ${ }^{2}$ Departamento de Genética, Escola Superior de Agricultura "Luiz de Queiroz", \\ Universidade de São Paulo, Piracicaba, SP, Brazil. \\ ${ }^{3}$ Centro Internacional de Mejoramiento de Maiz y Trigo, Cali, Colombia. \\ ${ }^{4}$ Centro Internacional de Mejoramiento de Maiz y Trigo, D.F., México.
}

\begin{abstract}
Breeding programs for acid-soil tolerance are desirable as a relatively inexpensive and permanent way for increasing maize (Zea mays L.) yield on these soils. Our objective was to compare the genetic effects controlling the expression of maize traits in acid and non-acid soils. Seven related and one unrelated inbred lines, with different levels of tolerance to acid soil, and their $\mathrm{F}_{1}, \mathrm{~F}_{2}, \mathrm{BC}_{1}$, and $\mathrm{BC}_{2}$ generations were evaluated in four acid and two non-acid soils. Estimates of additive, dominance, and epistatic effects were computed for grain yield, plant height, days to mid-silk, and prolificacy, using the generation means analysis procedure. For all traits the major part of the variation was accounted for by additive and dominance effects, with dominance effects being more important than additive and epistatic effects for both acid and non-acid soils. Epistatic effects were significant for some crosses only, being more pronounced for plant height than for the other traits. Furthermore, epistatic effects were randomly distributed among the crosses and were not related to the grain yield of the single-crosses $\left(F_{1}\right.$ 's $)$ and to the genetic relationships of the inbreds in either type of soil. The results suggest that similar pooled gene effects control the expression of the traits assessed in both acid and non-acid soils.
\end{abstract}

Key words: acid soils, additive, dominant, epistatic effects, generation analysis.

Received: June 8, 2007; Accepted: August 21, 2007.

\section{Introduction}

Soil acidity is a major yield-limiting factor for many crops and covers extensive areas in tropical, subtropical and temperate zones, with acid soils occupying about 3.95 billion hectares (about 30\%) of the world's ice-free land area (Von Uexkull and Mutert, 1995). The lower yield of crops grown in acid soils is because of combinations of low $\mathrm{pH}$, toxicity of $\mathrm{Al}, \mathrm{Mn}$, and $\mathrm{Fe}$, and deficiencies of $\mathrm{N}, \mathrm{P}, \mathrm{Ca}$, and $\mathrm{Mg}$. However, $\mathrm{Al}$ toxicity is the main problem because it inhibits maize root growth, reducing the water and nutrient uptake and interferes in different physiological process of crop development (Roy et al., 1988). About 20 million hectares of maize are currently grown under acid soils in the world (Von Uexkull and Mutert, 1995), and different strategies have been suggested to improve the productivity of these soils including lime application and the develop-

Send correspondence to Cláudio Lopes de Souza Jr. Departamento de Genética, Escola Superior de Agricultura "Luiz de Queiroz", Universidade de São Paulo, Caixa Postal 83, 13.400-970 Piracicaba, SP, Brazil. E-mail: clsouza@esalq.usp.br. ment of tolerant cultivars (Bahia Filho et al., 1997; Pandey and Gardner, 1992; Pandey et al., 2007).

Genetic variation for tolerance to soil acidity has been reported in several studies using different germplasm, different traits and different genetic analyses. Galvão and Silva (1978) reported that dominance variance was more important than additive variance for shoot and root dry weight in Al-stressed nutrient solution. Duque-Vargas et al. (1994), Borrero et al. (1995) and Narro et al. (2000) reported that dominance variance was either similar to or of greater importance than additive variance for yield under acid soils. On the other hand, reported results from diallel crosses studies carried out in acid soils have shown that for grain yield the general combining ability (additive effects) accounted for the major part of the total genetic variance, although specific combining ability (non-additive effects) were also significant, indicating that additive effects were more important than dominance and epistatic effects (Magnavaca et al., 1987a; Naspolini Filho et al., 1981; Lopes et al., 1987; Eleutério et al., 1988; Pandey et al., 1994; Salazar et al., 1997). Generation means analysis has also been 
used to estimate genetic effects from crosses between maize inbreds with different levels of tolerance to acid soil. Magnavaca et al. (1987b) reported that for relative seminal root length, additive effects accounted for the largest part of the variation, although dominance effects were significant in all instances and epistatic effects were significant in some crosses, but the magnitudes of the latter were lower than either additive or dominance effects. Ceballos et al. (1998) reported that for grain yield the additive-dominance model accounted for $91.1 \%$ of the variation in non-acid soils and $70.0 \%$ of the variation in acid soils, and that epistatic effects were more important in acid than in nonacid soils. Pandey et al. (2007) reported that the inheritance studies for grain yield in acid soils indicate that both additive and dominance effects are more important than epistatic effects.

Recurrent selection has been effective to improve maize grain yield in acid soils. Lima et al. (1992) reported that two cycles of mass selection for increasing radicle length in Al-stressed nutrient solution resulted in grain yield improvement in acid soils by $0.59 \mathrm{t} \mathrm{ha}^{-1}$ cycle $^{-1}(7.6 \%$ cy$\left.\mathrm{cle}^{-1}\right)$. Granados et al. (1993) reported yield improvement of $2.0 \%$ cycle $^{-1}$ after 14 cycles of modified ear-to-row selection and $7.0 \%$ cycle $^{-1}$ after two cycles of full-sib selection in acid soils. Ceballos et al. (1995) reported an average improvement of $4.9 \%$ cycle $^{-1}$ for grain yield in acid soils after two cycles of full-sib selection in five tropical maize populations.

The inheritance of several important traits in maize evaluated under non-acid soils has been well documented (Hallauer et al., 1988; Hallauer and Miranda Filho, 1988). Despite the large area of acid soils in South America and Africa, the information on the inheritance of maize agronomic traits in acid soils is quite limited. Thus, this research was conducted to estimate additive, dominance, and epistatic effects for several traits in maize in acid and in nonacid soil environments and to compare the inheritance of these traits in both environments.

\section{Materials and Methods}

Eight $\mathrm{S}_{8}$ maize inbred lines, selected from a group of 100 lines evaluated in Colombia during 1995 in acid-soils at Villavicencio ( $55 \% \mathrm{Al}$ saturation, $10 \mathrm{mg} \mathrm{kg}^{-1} \mathrm{P}$ ), and Santander de Quilichao (45\% Al saturation, $10 \mathrm{mg} \mathrm{kg}^{-1} \mathrm{P}$ ) and in non-acid soils at Palmira, Colombia, were used in this study. The traits used for selection were grain yield $\left(\mathrm{t} \mathrm{ha}^{-1}\right)$ and a score for tolerance to acid soils, 1 being highly tolerant and 5 highly sensitive. Seven inbred lines were derived from the same full-sib family from population SA4 and one inbred line from population SA5. Populations SA4 and SA5 are in different heterotic groups, adapted to tropical environments and have been improved using full-sib or $\mathrm{S}_{1}$ family recurrent selection (Pandey et al., 1995). Based on the mean grain yield in acid soil the inbreds were assigned into three groups: G1 which includes tolerant inbreds L1, L5 and L7; G2 includes sensitive inbreds L2, L3, L4 and L8; and G3, includes the moderately tolerant inbred L6. Inbreds of G1 and G2 consisted of sister lines because they were derived from the same full-sib family from SA4 population and L6 (G3) was derived from the SA5 population. In 1996 and 1997 growing seasons, the $\mathrm{F}_{1}, \mathrm{~F}_{2}, \mathrm{BC}_{1}$, and $\mathrm{BC}_{2}$ generations were developed for all crosses between these lines. The $\mathrm{F}_{1}$ 's were developed using a diallel mating scheme and at least 15 ears were saved to represent each $F_{1}$. The $F_{2}$ was developed by selfing the $\mathrm{F}_{1} ; \mathrm{BC}_{1}$ and $\mathrm{BC}_{2}$ refer to backcrosses of the $\mathrm{F}_{1}$ to $\mathrm{P}_{1}$ and to $\mathrm{P}_{2}$, respectively. At least 20 ears were saved for each of the $\mathrm{F}_{2}, \mathrm{BC}_{1}$ and $\mathrm{BC}_{2}$ generations. Thus, the experiment included 120 entries, i.e., eight inbred lines, $28 \mathrm{~F}_{1}$ 's, $28 \mathrm{~F}_{2}$ 's, and 56 BC's.

The 120 entries were evaluated in 1997, 1998 and 1999 growing seasons in four acid and two non-acid soil environments. Acid soil environments in Colombia were at Villavicencio in 1997 and 1998, at Santander de Quilichao in 1997 and at Sete Lagoas in Brazil in 1999. Non-acid soil environments were at Palmira, Colombia, in 1997 and 1998 (Table 1). The design used was the randomized complete block design with three replications per environment. Generations were allocated to different blocks and randomized independently. Plots were $2.5 \mathrm{~m}$ long and spaced $0.75 \mathrm{~m}$ between plots. Depending on the genetic uniformity of each generation, the plots had different number of rows. For the $\mathrm{P}_{1}, \mathrm{P}_{2}, \mathrm{~F}_{1}, \mathrm{BC}_{1}$ and $\mathrm{BC}_{2}$ generation the plots were two rows, whereas for the $\mathrm{F}_{2}$ generations four-row plots were used. The plots were overplanted and thinned to 20 plants plot $^{-1}$ for the $\mathrm{P}_{1}, \mathrm{P}_{2}, \mathrm{~F}_{1}, \mathrm{BC}_{1}$ and $\mathrm{BC}_{2}$ generations and to 40 plants plot $^{-1}$ for the $\mathrm{F}_{2}$ generation.

Data were recorded for grain yield $\left(\mathrm{t} \mathrm{ha} \mathrm{h}^{-1}\right)$, plant height $\left(\mathrm{cm} \mathrm{plant}^{-1}\right)$, stand (plants plot ${ }^{-1}$ ), grain moisture $\left(\mathrm{g} \mathrm{kg}^{-1}\right)$, number of ears per plot and number of days to mid-silk. Plant height was recorded in five competitive plants per plot, from the soil surface to the tip of the highest tassel branch, and the plot means were used for analysis. Prolificacy was computed per plot by the ratio number of ears per plot/stand. Days to mid-silk was recorded as the number of days from sowing to $50 \%$ of plants plot ${ }^{-1}$ with silk extrusion. Grain yield of each plot was adjusted for average stand by covariance analyses and for $150 \mathrm{~g} \mathrm{~kg}^{-1}$ of grain moisture.

Analyses of variances were performed for each environment and combined across environments for acid and for non-acid soils for each trait. In the combined analyses, environments and genotype by environment interaction were considered as random effects and genotypes as fixed effects. Genotypes sums of squares were orthogonally partitioned into parental lines, generations $\mathrm{F}_{1}, \mathrm{~F}_{2}, \mathrm{BC}_{1}, \mathrm{BC}_{2}$ and among generations, with genotype by environment interaction being partitioned accordingly. Thus, in the $F$ tests each partitioned source of variation was tested against its respective interaction with environment, and the partitioned genotypes by environment interaction were tested against the experimental error. 
Means of each generation across acid soil and across non-acid soil environments were independently subjected to generation mean analysis (Mather and Jinks, 1982). Following Gamble's (1962a) notation, the model used was: $g_{k}=m+(\alpha) a+(\beta) d+\left(\alpha^{2}\right) a a+(\alpha \beta) a d+\left(\beta^{2}\right) d d$, where $g_{k}$ is the mean across environments of the $k$ th generation, $m$ is the mean of two contrasting homozygotes (inbred parents), $a$ is the pooled additive effect, $d$ is the pooled dominance effect, $a a$ is the pooled additive $\mathrm{x}$ additive effect, $a d$ is the pooled additive $\mathrm{x}$ dominance effect, and $d d$ is the pooled dominance $\mathrm{x}$ dominance effect; $\alpha$ and $\beta$ are the coefficients of the genetic effects relating each generation to its mean.

Estimates of additive, dominance and epistatic effects were computed for each cross by weighted least square regression analysis (Mather and Jinks, 1982) using the equation $\mathbf{b}=\left(\mathbf{X}^{\prime} \mathbf{D}^{-1} \mathbf{X}\right)^{-1}\left(\mathbf{X}^{\prime} \mathbf{D}^{-1} \mathbf{y}\right)$, where $\mathbf{b}$ is the vector of genetic effects ( $m, a, d, a a, a d$, and $d d), \mathbf{X}$ is the incidence matrix of the genetic effects coefficients $\left(\alpha, \beta, \alpha^{2}, \alpha \beta\right.$, and $\left.\beta^{2}\right), \mathbf{y}$ is the column vector of the generation means and $\mathbf{D}^{-1}$ is a weighted diagonal matrix, where the diagonal elements were the reciprocals of the variances of each generation mean $\left(\mathrm{W}_{\mathrm{i}}\right)$, computed for each generation ( $\mathrm{P}$ 's, $\mathrm{F}_{1}$ 's, $\mathrm{F}_{2}$ 's, and $\mathrm{BC}$ 's) as the generation by environment interaction mean squares $\left(\mathrm{MSI}_{\mathrm{i}}\right)$ divided by the number of locations $(\mathrm{L})$ and replications $(\mathrm{R})$; i.e.: $\mathrm{W}_{\mathrm{i}}=\left(\mathrm{MSI}_{\mathrm{i}} / \mathrm{LR}\right)^{-1}$.

Estimates of additive, dominance and epistatic effects were computed by analyzing the sequential sums of squares calculated from the addition of each genetic effect in the model. The relative importance of the genetic effect estimates was determined using the ratio of the sequential sum of squares and total sum of squares, after sequentially entering the different effects into the model. A Chi-square $\left(\chi^{2}\right)$ test was used to examine the adequacy of a reduced model with only additive $(a)$ and dominance $(d)$ effects. Whenever the chi-square test was significant, the epistatic effects $a a$, $a d$, and $d d$ were incorporated sequentially into the model (Allen and Cady, 1982). Standard errors of the estimates of the genetic effects were obtained from the diagonal elements of $\mathbf{W}=\left[\left(\mathbf{X}^{\prime} \mathbf{D}^{-1} \mathbf{X}\right)^{-1}\right]^{1 / 2}$ matrix.

\section{Results and Discussion}

\section{Means and analyses of variance}

Average grain yield in the non-acid soil was highly significantly $(p=0.01)$ greater than the average of the acid soil environments $\left(3.19 \mathrm{t} \mathrm{ha}^{-1}\right.$ vs. $\left.1.58 \mathrm{tha}^{-1}\right)$. Average grain yield of the tolerant set (G1) of parental inbreds $\left(1.10 \mathrm{tha}^{-1}\right)$ presented highly significant differences from the sensitive set (G2) of parental inbreds $\left(0.67 \mathrm{t} \mathrm{ha}^{-1}\right)$ in acid soils, indicating that the selection within a full-sib family for tolerance to acid soil environments was effective. In non-acid soils, parental inbreds mean yields of G1 $\left(1.30 \mathrm{tha}^{-1}\right)$ and G2 $\left(1.00 \mathrm{t} \mathrm{ha}^{-1}\right)$ did not differ significantly. Plant height $\left(171 \mathrm{~cm}^{-1 a n t^{-1}}\right.$ vs. $\left.127 \mathrm{~cm} \mathrm{plant}^{-1}\right)$ and prolificacy $(0.98$ ears plant ${ }^{-1}$ vs. 0.89 ears plant $^{-1}$ ) were also significantly $(p=0.05)$ greater in non-acid than in acid soils. For days to mid-silk there was no difference between the two soil types (59 vs. 60 days) (Table 1).

For all generations, the mean grain yield decreased significantly in acid relative to the non-acid soil environments. Grain yield means in non-acid soil and acid soil environments were $1.14 \mathrm{t} \mathrm{ha}^{-1}$ and $0.86 \mathrm{t} \mathrm{ha}^{-1}$ for the parents; $4.18 \mathrm{t} \mathrm{ha}^{-1}$ and $1.97 \mathrm{t} \mathrm{ha}^{-1}$ for the $\mathrm{F}_{1}$ 's; $3.02 \mathrm{t} \mathrm{ha}^{-1}$ and $1.52 \mathrm{tha}^{-1}$ for the $\mathrm{F}_{2}$ 's; and $3.07 \mathrm{tha}^{-1}$ and $1.52 \mathrm{t} \mathrm{ha}^{-1}$ for the average of BC's, respectively (Table 2). The detrimental effects of soil acidity on maize grain yield have been reported by Granados et al. (1993), Duque-Vargas et al. (1994), Borrero et al. (1995), Ceballos et al. (1998).

The combined analyses of variance across environments (data not shown) showed significant differences among environments for all traits evaluated in acid and non-acid soils. In acid soils, highly significant differences were detected for parental inbreds, $F_{1}$ 's, $F_{2}$ 's, BC's, and among generations for grain yield, days to mid-silk and plant height, whereas for prolificacy inbreds and among generations were not significant. For grain yield all generations and among generations interacted significantly with environments, whereas for days to mid-silk only the $F_{2}$ 's generation were not significant and for plant height and prolificacy only among generations were significant. In

Table 1 - Environmental characteristics and overall means for maize grain yield, mid-silk, plant height and prolificacy, evaluated in four acid soil and at two non-acid soils environments in Brazil and Colombia.

\begin{tabular}{|c|c|c|c|c|c|c|c|c|c|c|}
\hline $\begin{array}{l}\text { Environment/ } \\
\text { Year }^{1}\end{array}$ & $\begin{array}{l}\text { Lat. } \\
\left({ }^{\circ}\right)\end{array}$ & $\begin{array}{l}\text { Long. } \\
\left({ }^{\circ}\right)\end{array}$ & $\begin{array}{c}\text { Altitude } \\
\text { (masl) }\end{array}$ & $\mathrm{pH}$ & $\begin{array}{c}\mathrm{P} \\
\left(\mathrm{mg} \mathrm{kg}^{-1}\right)\end{array}$ & $\begin{array}{c}\text { Al sat. } \\
(\%)\end{array}$ & $\begin{array}{l}\text { Yield } \\
\left(\mathrm{t} \mathrm{ha}^{-1}\right)\end{array}$ & $\begin{array}{c}\text { Mid-silk } \\
\text { (days) }\end{array}$ & $\begin{array}{l}\text { Plant height } \\
(\mathrm{cm})\end{array}$ & $\begin{array}{c}\text { Prolificacy } \\
\left(\text { ears plant }^{-1}\right)\end{array}$ \\
\hline Villavicencio/ 97 & $4^{\circ} 06^{\prime} \mathrm{N}$ & $73^{\circ} 29^{\prime} \mathrm{W}$ & 400 & 4.5 & 8.0 & 55 & 1.20 & 59 & 128 & 0.85 \\
\hline Villavicencio/ 98 & $4^{\circ} 06^{\prime} \mathrm{N}$ & $73^{\circ} 29^{\prime} \mathrm{W}$ & 400 & 4.8 & 8.5 & 55 & 1.30 & 58 & 118 & 0.83 \\
\hline S. Quilichao/ 97 & $3^{\circ} 06^{\prime} \mathrm{N}$ & $76^{\circ} 30^{\prime} \mathrm{W}$ & 1052 & 4.5 & 9.0 & 52 & 1.90 & 66 & 129 & 0.90 \\
\hline Sete Lagoas/ 99 & $19^{\circ} 27^{\prime} \mathrm{S}$ & $44^{\circ} 14^{\prime} \mathrm{W}$ & 716 & 4.8 & 4.0 & 45 & 1.93 & 55 & 134 & 0.99 \\
\hline Palmira/ 97 & $3^{\circ} 30^{\prime} \mathrm{N}$ & $76^{\circ} 19^{\prime} \mathrm{W}$ & 965 & 6.6 & $>60$ & $<1$ & 3.33 & 58 & 180 & 1.00 \\
\hline Palmira/ 98 & $3^{\circ} 30^{\prime} \mathrm{N}$ & $76^{\circ} 19^{\prime} \mathrm{W}$ & 965 & 6.6 & $>60$ & $<1$ & 3.05 & 59 & 162 & 0.95 \\
\hline
\end{tabular}

${ }^{1}$ Villavicencio and S.Quilichao in Colombia, and Sete Lagoas in Brazil are acid soils environments, and Palmira in Colombia is a non-acid soil environment. 
non-acid soils all generations and among generations were highly significant, except parental inbreds, for grain yield, mid-silk, and prolificacy; also for prolificacy only the $\mathrm{F}_{2}$ 's and BC's were significant. The partitioned generation by environment interactions was not significant for parental inbreds for all traits, except prolificacy; for the $\mathrm{F}_{1}$ 's significance was detected only for grain yield and prolificacy; for the $\mathrm{F}_{2}$ 's no significance was detected for all traits; for the BC's interaction was significant for grain yield and mid-silk; and for among generations all traits interacted significant with environments, except plant height.

\section{Genetic effects}

The genetic analysis across acid soil and non-acid soil environments showed that for most of the crosses a large proportion of the total sum of squares $\left(R^{2}\right)$ for grain yield was accounted for by additive and dominance effects. In acid soils the $R^{2}$ values averaged $93.2 \%$ and ranged from $49.5 \%$ to $99.9 \%$, while in non-acid soils the $R^{2}$ values averaged $96.0 \%$ and ranged from $78.7 \%$ to $99.9 \%$. The $\chi^{2}$ values for the three-parameter model $(\mathrm{m}, \mathrm{a}, \mathrm{d})$ were nonsignificant for $24(85.7 \%)$ and for $22(78.6 \%)$ out of the 28 crosses in acid and non-acid soils, respectively. Therefore, the three-parameter model explained a major portion of total genetic variation for grain yield in acid and non-acid soils. In acid soils, two crosses involving related inbreds within the G1 group and one cross within the G2 group did not show any significant genetic effects except the mean parameter (Tables 2 and 3).

In acid soils pooled additive genetic effects for grain yield were significant for 17 out of the 28 crosses $(60.7 \%)$. The magnitude in absolute values of the additive effects

Table 2 - Means of six maize generations using eight inbreds with different levels of tolerance to acid soils, and estimates of mean ( $\mathrm{m}$ ), additive ( $a$ ), dominance $(d)$ and epistatic $(a a, a d, d d)$ effects, for grain yield evaluated in four acid soils environments in Brazil and Colombia.

\begin{tabular}{|c|c|c|c|c|c|c|c|c|c|c|c|c|c|}
\hline Cross $^{1}$ & $\mathrm{P}_{1}$ & $\mathrm{P}_{2}$ & $\mathrm{~F}_{1}$ & $\mathrm{~F}_{2}$ & $\mathrm{BC}_{1}$ & $\mathrm{BC}_{2}$ & $\mathrm{~m}\left(\mathrm{t} \mathrm{ha}{ }^{-1}\right)$ & $a$ & $d$ & $a a$ & $a d$ & $d d$ & $\mathrm{R}^{22}$ \\
\hline L1 x L5 & 1.23 & 1.07 & 1.10 & 1.40 & 1.26 & 1.22 & $1.17 * *$ & 0.08 & 0.11 & - & - & - & 49.52 \\
\hline L1 x L7 & 1.23 & 0.96 & 1.16 & 1.28 & 1.14 & 1.11 & $1.10^{* *}$ & $0.12 *$ & 0.11 & - & - & - & 83.43 \\
\hline L5 x L7 & 1.07 & 0.96 & 1.39 & 1.18 & 1.01 & 1.04 & $1.00 * *$ & 0.05 & 0.25 & - & - & - & 65.37 \\
\hline L2 x L3 & 0.82 & 0.61 & 0.98 & 0.89 & 0.85 & 0.96 & $0.72 * *$ & 0.09 & $0.31 *$ & - & - & - & 85.44 \\
\hline L2 x L4 & 0.82 & 0.67 & 0.99 & 0.95 & 1.01 & 0.90 & $0.75^{* *}$ & 0.08 & $0.33 *$ & - & - & - & 93.53 \\
\hline L3 x L4 & 0.61 & 0.67 & 0.91 & 0.79 & 0.68 & 0.92 & $0.64 * *$ & -0.04 & 0.29 & - & - & - & 79.95 \\
\hline L3 x L8 & 0.61 & 0.59 & 1.56 & 1.65 & 1.21 & 1.44 & $1.71 * *$ & 0.00 & -0.16 & $-1.11 * *$ & - & - & 98.37 \\
\hline L4 x L8 & 0.67 & 0.59 & 1.31 & 1.25 & 1.16 & 1.37 & $0.65 * *$ & 0.02 & $0.96 * *$ & - & - & - & 86.03 \\
\hline L1 x L2 & 1.23 & 0.82 & 2.02 & 1.60 & 1.70 & 1.47 & $1.03 * *$ & $0.21 * *$ & $1.08 * *$ & - & - & - & 99.52 \\
\hline L1 x L3 & 1.23 & 0.61 & 2.20 & 1.61 & 1.79 & 1.69 & $0.93 * *$ & $0.29 * *$ & $1.41 * *$ & - & - & - & 97.81 \\
\hline L1 x L8 & 1.23 & 0.59 & 2.14 & 1.45 & 1.60 & 1.47 & $0.91 * *$ & $0.31 * *$ & $1.22 * *$ & - & - & - & 98.91 \\
\hline L2 x L5 & 0.82 & 1.07 & 2.02 & 1.82 & 1.46 & 1.60 & $0.96 * *$ & $-0.13 *$ & $1.21 * *$ & - & - & - & 94.89 \\
\hline L3 x L5 & 0.61 & 1.07 & 2.16 & 1.80 & 1.48 & 1.74 & $0.86^{* *}$ & $-0.23 * *$ & $1.48 * *$ & - & - & - & 97.59 \\
\hline L4 x L5 & 0.67 & 1.07 & 2.25 & 1.60 & 1.58 & 1.70 & $0.87 * *$ & $-0.19 * *$ & $1.45 * *$ & - & - & - & 99.50 \\
\hline L5 x L8 & 1.07 & 0.59 & 1.88 & 1.47 & 1.79 & 1.28 & $0.84 * *$ & $0.26^{* *}$ & $1.21 * *$ & - & - & - & 96.16 \\
\hline $\mathrm{L} 2 \times \mathrm{L} 7$ & 0.82 & 0.96 & 2.16 & 1.46 & 1.50 & 1.69 & $0.89 * *$ & -0.08 & $1.30 * *$ & - & - & - & 98.85 \\
\hline L3 x L7 & 0.61 & 0.96 & 2.30 & 1.76 & 1.50 & 2.10 & $0.81 * *$ & $-0.18 * *$ & $1.74 * *$ & - & $-0.84^{*}$ & - & 97.62 \\
\hline L4 x L7 & 0.67 & 0.96 & 2.23 & 1.45 & 1.32 & 1.71 & $0.81 * *$ & $-0.17 * *$ & $1.39 * *$ & - & - & - & 98.54 \\
\hline L7 x L8 & 0.96 & 0.59 & 1.99 & 1.50 & 1.67 & 1.39 & $0.79 * *$ & $0.20 * *$ & $1.35 * *$ & - & - & - & 98.57 \\
\hline L1 x L6 & 1.23 & 0.93 & 2.87 & 1.95 & 2.10 & 1.87 & $1.08 * *$ & $0.16^{* *}$ & $1.79 * *$ & - & - & - & 99.88 \\
\hline L2 x L6 & 0.82 & 0.93 & 2.55 & 1.75 & 1.71 & 1.78 & $0.88^{* *}$ & -0.06 & $1.71 * *$ & - & - & - & 99.93 \\
\hline L3 x L6 & 0.61 & 0.93 & 2.66 & 1.70 & 1.72 & 1.70 & $0.77 * *$ & $-0.14 * *$ & $1.90 * *$ & - & - & - & 99.51 \\
\hline L5 x L6 & 1.07 & 0.93 & 2.98 & 1.85 & 1.89 & 2.08 & $0.99 * *$ & 0.05 & $1.94 * *$ & - & - & - & 98.69 \\
\hline L6 x L7 & 0.93 & 0.96 & 2.80 & 1.89 & 1.66 & 2.31 & $0.95 * *$ & -0.02 & $1.93 * *$ & - & $1.26^{* *}$ & - & 99.60 \\
\hline L6 x L8 & 0.93 & 0.59 & 2.25 & 1.65 & 1.74 & 1.76 & $0.78 * *$ & $0.16^{* *}$ & $1.69 * *$ & - & - & - & 97.14 \\
\hline $\operatorname{LSD}(0.05)$ & 0.25 & 0.25 & 0.66 & 0.53 & 0.54 & 0.54 & & & & & & & \\
\hline
\end{tabular}

$*$,**Significant at $\mathrm{p}=0.05$ and at $\mathrm{p}=0.01$, respectively.

${ }^{1}$ L1, L5 and L7 belong to G1 (tolerant), and L2, L3, L4 and L8 belong to G2 (sensitive), both groups derived from SA4 population. L6 was derived from SA5 population.

${ }^{2} \mathrm{R}^{2}$ is the proportion of the total sums of squares accounted for by the model. 
were larger for crosses among tolerant (G1) x sensitive (G2) related lines from the same full-sib family $\left(0.21 \mathrm{tha}^{-1}\right)$, than for crosses of unrelated SA5 $\mathrm{x}$ SA4 lines $\left(0.10 \mathrm{tha}^{-1}\right)$, and, also, larger than G1 x G1 related crosses $\left(0.08 \mathrm{tha}^{-1}\right)$ and than G2 x G2 related crosses $\left(0.06 \mathrm{tha}^{-1}\right)$. In non-acid soil, estimates of additive effects were significant only for six out of 28 crosses (21.4\%); thus, the pooled additive effects were more important in acid than in nonacid soils to explain the genetic variation among generations. However, the mean additive effects for acid soils did not differ significantly from that of non-acid soil $\left(1.34 \mathrm{tha}^{-1}\right.$ vs. $\left.1.39 \mathrm{t} \mathrm{ha}^{-1}\right)$, suggesting that the estimates of the pooled additive effects were not affected by soil acidity. Also, the relatedness or the tolerance/sensitivity of the parental inbreds to acid soils had no effect on the estimates of the additive effects under non-acid soils (Tables 2 and 3 ).
The pooled dominance effects for grain yield were significant for $22(78.6 \%)$ and for $28(100 \%)$ crosses in acid and non-acid soils, respectively. The magnitude of these effects was greater than the mean parameter, except for eight crosses in acid soil and six crosses in non-acid soil. Also, these effects were positive for most of the crosses, except for two crosses in acid and one cross in non-acid soil. For acid soil the significant dominance effects averaged $1.11 \mathrm{t}$ $\mathrm{ha}^{-1}$ and ranged from $0.31 \mathrm{tha}^{-1}$ to $1.94 \mathrm{tha}^{-1}$, whereas for non-acid soil the dominance effects averaged $3.06 \mathrm{tha}^{-1}$ and ranged from $-0.99 \mathrm{tha}^{-1}$ to $6.95 \mathrm{tha}^{-1}$. Thus, contrary to the additive effects, the magnitudes of the dominance effects were significantly affected by soil acidity. Also, the pooled dominance effects were dependent on the genetic relatedness and on the level of sensitivity to soil acidity of the parental inbreds. Crosses including unrelated (G1 x G3 and

Table 3 - Means of six maize generations using eight inbreds with different levels of tolerance to acid soils, and estimates of mean (m), additive ( $a$ ), dominance $(d)$ and epistatic $(a a, a d, d d)$ effects, for grain yield evaluated in two non-acid soils environments in Colombia.

\begin{tabular}{|c|c|c|c|c|c|c|c|c|c|c|c|c|c|}
\hline Cross $^{1}$ & $\mathrm{P}_{1}$ & $\mathrm{P}_{2}$ & $\mathrm{~F}_{1}$ & $\mathrm{~F}_{2}$ & $\mathrm{BC}_{1}$ & $\mathrm{BC}_{2}$ & $\mathrm{~m}\left(\mathrm{t} \mathrm{ha}^{-1}\right)$ & $a$ & $d$ & $a a$ & $a d$ & $d d$ & $\mathrm{R}^{22}$ \\
\hline L1 x L5 & 1.26 & 1.14 & 1.93 & 1.97 & 2.09 & 2.17 & $1.26^{* *}$ & 0.05 & $1.20 * *$ & - & - & - & 78.72 \\
\hline L1 x L7 & 1.26 & 1.50 & 2.15 & 2.31 & 2.20 & 2.30 & $1.44 * *$ & -0.12 & $1.25^{* *}$ & - & - & - & 80.96 \\
\hline L5 x L7 & 1.14 & 1.50 & 2.02 & 2.00 & 1.84 & 2.10 & $1.36^{* *}$ & -0.19 & $-0.99 * *$ & - & - & - & 88.84 \\
\hline L2 x L3 & 1.29 & 0.85 & 2.35 & 2.00 & 1.99 & 1.65 & $1.09 * *$ & $0.23^{*}$ & $1.46^{* *}$ & - & - & - & 96.56 \\
\hline L2 x L4 & 1.29 & 0.78 & 2.28 & 2.02 & 2.37 & 1.73 & $1.08^{* *}$ & $0.28^{*}$ & $1.60 * *$ & - & - & - & 91.58 \\
\hline L2 x L8 & 1.29 & 1.10 & 3.07 & 2.14 & 2.11 & 2.76 & $1.21 * *$ & 0.04 & $2.04 * *$ & - & - & - & 91.83 \\
\hline L3 x L4 & 0.85 & 0.78 & 2.16 & 1.53 & 1.20 & 1.87 & $0.82 * *$ & -0.02 & $1.39 * *$ & - & - & - & 89.51 \\
\hline L3 x L8 & 0.85 & 1.10 & 3.30 & 2.82 & 2.33 & 2.89 & $2.39 * *$ & -0.16 & $0.97 * *$ & $-1.41^{*}$ & - & - & 98.82 \\
\hline L4 x L8 & 0.78 & 1.10 & 3.11 & 2.42 & 2.08 & 2.60 & $0.98 * *$ & -0.19 & $2.49 * *$ & - & - & - & 96.41 \\
\hline L1 x L2 & 1.26 & 1.29 & 4.87 & 3.41 & 3.33 & 3.34 & $1.31 * *$ & -0.01 & $3.87 * *$ & - & - & - & 99.10 \\
\hline L1 x L3 & 1.26 & 0.85 & 4.19 & 3.41 & 3.21 & 3.34 & $2.71 * *$ & 0.18 & $1.60^{*}$ & $-1.64 * *$ & - & - & 99.10 \\
\hline L1 x L4 & 1.26 & 0.78 & 4.48 & 3.00 & 2.97 & 3.39 & $1.06^{* *}$ & 0.19 & $3.79 * *$ & - & - & - & 97.28 \\
\hline L1 x L8 & 1.26 & 1.10 & 4.00 & 2.66 & 2.59 & 3.12 & $1.20 * *$ & 0.03 & $2.98 * *$ & - & - & - & 97.33 \\
\hline L2 x L5 & 1.29 & 1.14 & 5.06 & 3.42 & 3.47 & 3.29 & $1.24 * *$ & 0.08 & $4.09 * *$ & - & - & - & 99.37 \\
\hline L3 x L5 & 0.85 & 1.14 & 4.27 & 3.29 & 3.35 & 3.54 & $2.49 * *$ & -0.15 & $2.01^{*}$ & $-1.46^{*}$ & - & - & 98.19 \\
\hline L4 x L5 & 0.78 & 1.14 & 5.02 & 3.40 & 3.10 & 3.50 & $1.00 * *$ & -0.20 & $4.39 * *$ & - & - & - & 98.92 \\
\hline L5 x L8 & 1.14 & 1.10 & 4.40 & 3.16 & 2.98 & 3.40 & $1.17 * *$ & -0.01 & $3.66^{* *}$ & - & - & - & 97.53 \\
\hline L2 x L7 & 1.29 & 1.50 & 4.35 & 3.20 & 3.26 & 3.60 & $1.45^{* *}$ & -0.13 & $3.38 * *$ & - & - & - & 96.79 \\
\hline L3 x L7 & 0.85 & 1.50 & 4.56 & 3.65 & 3.19 & 4.51 & $1.18^{* *}$ & $-0.33 * *$ & $6.95 * *$ & - & $-1.98 *$ & $-3.56^{*}$ & 99.08 \\
\hline L4 x L7 & 0.78 & 1.50 & 5.08 & 3.36 & 3.41 & 3.76 & $1.18^{* *}$ & $-0.36^{* *}$ & $4.29 * *$ & - & - & - & 98.73 \\
\hline L7 x L8 & 1.50 & 1.10 & 4.47 & 3.45 & 3.87 & 3.38 & $2.60 * *$ & $0.22 *$ & $2.08^{* *}$ & $-1.27 *$ & - & - & 97.98 \\
\hline L1 x L6 & 1.26 & 1.17 & 5.33 & 3.90 & 4.07 & 3.71 & $2.59 * *$ & 0.07 & $2.89^{*}$ & $-1.35^{*}$ & - & - & 99.27 \\
\hline L2 x L6 & 1.29 & 1.17 & 5.62 & 3.61 & 3.82 & 3.40 & $1.25^{* *}$ & 0.08 & $4.57 * *$ & - & - & - & 99.48 \\
\hline L3 x L6 & 0.85 & 1.17 & 5.53 & 3.71 & 3.56 & 3.67 & $1.06^{* *}$ & -0.16 & $4.88^{* *}$ & - & - & - & 99.04 \\
\hline L4 x L6 & 0.78 & 1.17 & 5.83 & 3.60 & 3.68 & 3.39 & $0.99 * *$ & -0.16 & $5.01 * *$ & - & - & - & 99.40 \\
\hline L5 x L6 & 1.14 & 1.17 & 6.07 & 3.88 & 3.88 & 3.20 & $1.17 * *$ & 0.04 & $4.49 * *$ & - & - & - & 98.67 \\
\hline L6 x L7 & 1.17 & 1.50 & 6.19 & 3.98 & 3.59 & 4.56 & $1.37 * *$ & $-0.22 *$ & $5.10^{* *}$ & - & - & - & 98.50 \\
\hline L6 x L8 & 1.17 & 1.10 & 5.43 & 3.35 & 3.26 & 3.30 & $1.14 * *$ & 0.03 & $4.32 *$ & - & - & - & 99.95 \\
\hline $\operatorname{LSD}(0.05)$ & 0.50 & 0.50 & 1.22 & 0.81 & 1.09 & 1.09 & & & & & & & \\
\hline
\end{tabular}

$*, * *$ Significant at $\mathrm{p}=0.05$ and at $\mathrm{p}=0.01$, respectively.

${ }_{1}^{1} \mathrm{~L} 1, \mathrm{~L} 5$ and L7 belong to G1 (tolerant), and L2, L3, L4 and L8 belong to G2 (sensitive), both groups derived from SA4 population. L6 was derived from SA5 population.

${ }^{2} R^{2}$ is the proportion of the total sums of squares accounted for by the model. 
G2 x G3) lines had the largest estimates (1.80 $\mathrm{t} \mathrm{ha}^{-1} v s$. $\left.4.47 \mathrm{tha}^{-1}\right)$, followed by tolerant $(\mathrm{G} 1) \times$ sensitive $(\mathrm{G} 2)$ related crosses $\left(1.34 \mathrm{tha}^{-1}\right.$ vs. $\left.3.60 \mathrm{t} \mathrm{ha}^{-1}\right)$, by sensitive $(\mathrm{G} 1) \mathrm{x}$ sensitive (G1) related crosses $\left(0.29 \mathrm{tha}^{-1} v s .1 .66 \mathrm{tha}^{-1}\right)$ and by tolerant $(\mathrm{G} 2) \times$ tolerant $(\mathrm{G} 2)$ related crosses $\left(0.16 \mathrm{tha}^{-1}\right.$ vs. $1.15 \mathrm{t} \mathrm{ha}^{-1}$ ) (Tables 2 and 3 ). As expected, crosses between unrelated inbreds presented larger dominance effects (Hallauer and Miranda Filho, 1988). The results from crosses between related lines suggested that selection within the full-sib family for tolerance to soil acidity increased the genetic diversity of the lines, because G1 x G2 crosses presented significantly larger dominance effects than G1 x G1 and than G2 x G2 crosses for both types of soils. These results suggest that unidirectional positive dominance plays an important role in the inheritance of grain yield in both acid and non-acid soils. The importance of dominance genetic effects for the inheritance of grain yield in maize in non-acid soils has been reported (Gamble, 1962a; Darrah and Hallauer, 1972; Cockerham and Zeng, 1996), but for acid soils the available information is limited. Ceballos et al. (1998) reported that, for grain yield, the dominance effects accounted for $63.0 \%$ and $81.0 \%$ of the total sum of squares in acid and non-acid soils, respectively, and that the estimates of dominance effects were affected by soil acidity; i.e., dominance effect estimates in acid soil were significant lower than those in non-acid soils.

Epistatic effects for grain yield were detected in four out of 28 crosses $(14.3 \%)$ in acid soils, with aa effects in two crosses, $a d$ effects in three crosses, and both $a a$ and $a d$ were detected simultaneously in only one cross. In non-acid soils, six crosses $(21.4 \%)$ presented significant epistatic effects, with $a a$ effects in five crosses and $a d$ and $d d$ effects in one cross. There was no connection between the relatedness of the inbreds and epistatic effects. The number of crosses with epistatic effects was slightly greater in nonacid than in acid soils, and the magnitudes of these effects were also larger in non-acid than in acid soils (Tables 2 and 3). Narro et al. (2000) conducted a diallel analysis in acid soils and reported that both additive effects (general combining ability) and non-additive effects (specific combining ability) were equally important for grain yield. Ceballos et al. (1998) reported that epistatic effects for grain yield were important in acid soils but not for non-acid soils. Our results did not agree with those reported by Ceballos et al. (1998) because epistatic effects were detected in both types of soils for only four crosses in acid soil and six crosses in non-acid soil, suggesting that soil acidity could not affect the detection of epistatic effects. These results also did not agree with those of Wolf and Hallauer (1997) who reported that epistasis in maize seems to be more important in either poorer or better environments. Jinks et al. (1973) also reported that the frequency and magnitude of epistasis in tobacco (Nicotiana tabacum L.) were greater in both extremes of a range of environments. Epistatic effects for grain yield of maize in non-acid soils have been reported to be lower than for its components, such as ear length, ear diameter, and kernel-row number (Gamble, 1962a; Gamble 1962b; Darrah and Hallauer, 1972; Wolf and Hallauer, 1997), but these information are lacking for acid soils.

For plant height, the number of crosses in acid soils with significant additive effects $(53.6 \%)$ was greater than those with significant epistatic effects $(50 \%)$ followed by those with significant dominance effects $(42.9 \%)$, whereas in non-acid soils, dominance effects were significant for $71.5 \%$, epistatic effects for $53.6 \%$ and additive effects for $50.0 \%$ of the crosses (Table 4 ). Both additive and dominance effects were not affected by the genetic relatedness of the inbreds but they were significantly reduced by soil acidity; the additive effects were less affected $(5.5 \mathrm{~cm}$ plant $^{-1}$ vs. $7.5 \mathrm{~cm}$ plant $\left.^{-1}\right)$ than dominance effects $(20.0 \mathrm{~cm}$ plant $^{-1}$ vs. $48.7 \mathrm{~cm}$ plant $^{-1}$ ) by soil acidity. All estimates of epistatic effects were negative in both soils, with $a a$ effects being more important than the other types of digenic epistasis in acid soil while $a a$ and $d d$ were more important than ad effects in non-acid soil. Similar results for plant height in non-acid soils; i.e., dominance effects more important than additive and epistatic effects, with $a a$ and $d d$ effects more important than ad effects were reported by Gamble (1962b), Darrah and Hallauer (1972), and Moreno-Gonzalez and Dudley (1981). However, Narro et al. (2000) reported that non-additive effects (dominance and epistasis) were as important as additive effects for plant height in acid soils.

For mid-silk in acid soil the pooled additive effects were significant for 11 crosses $(39.3 \%)$, pooled dominance effects for 21 crosses $(75.0 \%)$ and pooled epistatic effects for two crosses $(9.5 \%)$, while in non-acid soil 2 (7.14\%), 22 $(78.57 \%)$ and 7 crosses $(25 \%)$ presented significant additive, dominant, and epistatic pooled effects, respectively. In absolute values the additive effects averaged $0.8 \mathrm{~d}$ and $0.7 \mathrm{~d}$ and the dominance effects averaged $3.6 \mathrm{~d}$ and $4.7 \mathrm{~d}$ in acid and in non-acid soils, respectively. Most of the dominance effects were negative, and most of epistatic effects were positive in both soils (Table 5). Darrah and Hallauer (1972) reported that dominance was the major effect in the inheritance of this trait, followed by additive and epistatic effects. Wolf and Hallauer (1997) also detected significant epistatic effects for mid-silk.

For prolificacy (data not shown), only one cross presented significant pooled additive and epistatic effects, and 12 crosses $(42.9 \%)$ presented significant pooled dominance effects in acid soils, while in non-acid soils only one cross presented significant pooled additive and dominance effects. No significance was detected among parental lines in the joint analysis of variance indicating that the genetic divergence of the parental lines for prolificacy was very low. Thus, the lower number of crosses with significant genetic effects could be attributable to the lower genetic divergence of the parental inbreds for this trait. Wolf and Hallauer 


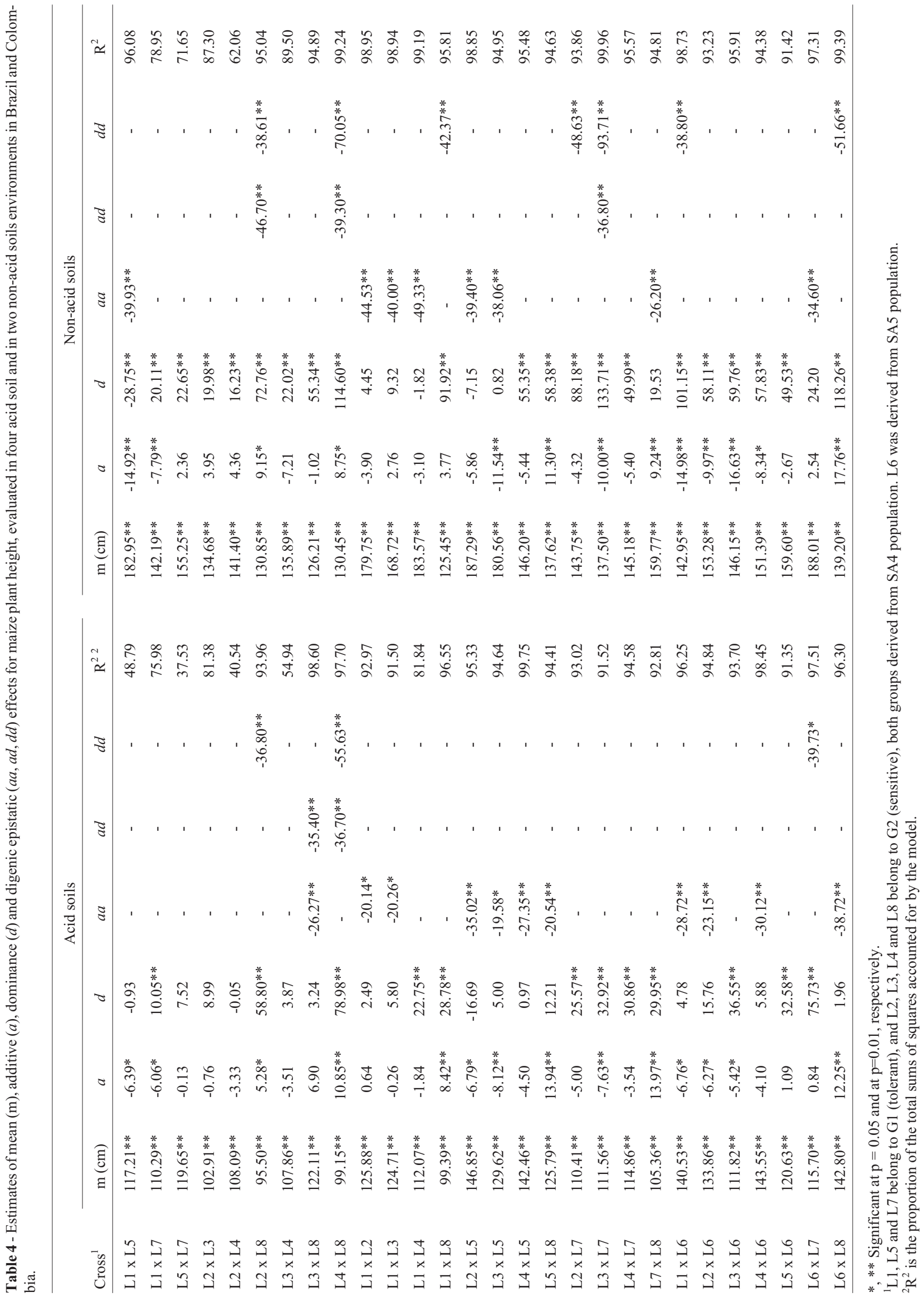


Table 5 - Estimates of mean (m), additive $(a)$, dominance $(d)$ and digenic epistatic $(a a, a d, d d)$ effects for maize mid-silk, evaluated in four acid soil and in two non-acid soils environments in Brazil and Colombia.

\begin{tabular}{|c|c|c|c|c|c|c|c|c|c|c|c|c|c|c|}
\hline \multirow[b]{2}{*}{ Cross $^{1}$} & \multicolumn{7}{|c|}{ Acid soils } & \multicolumn{7}{|c|}{ Non-acid soils } \\
\hline & m (days) & $a$ & $d$ & $a a$ & $a d$ & $d d$ & $\mathrm{R}^{22}$ & m (days) & $a$ & $d$ & $a a$ & $a d$ & $d d$ & $\mathrm{R}^{2}$ \\
\hline L1 x L5 & $62.34 * *$ & -0.07 & 0.58 & - & - & - & 12.53 & $63.09 * *$ & 0.91 & -0.70 & - & - & - & 26.57 \\
\hline L1 $1 \times$ L7 & $62.51 * *$ & -0.20 & -0.08 & - & - & - & 16.04 & $62.14 * *$ & 0.99 & -0.46 & - & - & - & 45.63 \\
\hline L5 $\times$ L7 & $62.93 * *$ & 0.15 & -0.56 & - & - & - & 51.01 & $62.13 * *$ & 0.82 & 0.46 & - & - & - & 66.05 \\
\hline L2 $\times$ L 3 & $60.69 * *$ & $0.92 *$ & -0.71 & - & - & - & 89.54 & $62.35 * *$ & 0.58 & $-3.36^{* *}$ & - & - & - & 81.35 \\
\hline $\mathrm{L} 2 \times \mathrm{L} 4$ & $61.62 * *$ & -0.05 & -0.33 & - & - & - & 17.02 & $62.79 * *$ & -0.35 & $-3.80^{* *}$ & - & - & - & 76.75 \\
\hline L2 $x$ L8 & $61.47^{* *}$ & 0.58 & $-3.69^{* *}$ & - & - & - & 81.81 & $62.13 * *$ & 0.90 & $-4.98^{* *}$ & - & - & - & 89.17 \\
\hline L3 $\times$ L4 & $60.63 * *$ & -0.92 & 0.32 & - & - & - & 65.82 & $61.18^{* *}$ & -0.33 & $-2.46^{* *}$ & - & - & - & 68.23 \\
\hline L3 $\times$ L8 & $59.95 * *$ & -0.48 & $-3.83 * *$ & - & - & - & 85.52 & $68.85 * *$ & -0.03 & $-5.45^{* *}$ & - & - & $\begin{array}{l}1 \\
1.20^{* *}\end{array}$ & 98.63 \\
\hline L4 x L8 & $61.07 * *$ & 0.69 & $-2.31 * *$ & - & - & - & 78.05 & $61.60 * *$ & 0.70 & $-15.80 * *$ & - & - & - & 99.80 \\
\hline L1 $\times$ L2 & $61.92 * *$ & 0.25 & $-4.58 * *$ & - & - & - & 91.99 & $63.06^{* *}$ & 0.53 & $-7.08 * *$ & - & - & - & 97.39 \\
\hline L1 $x$ L3 & $60.96^{* *}$ & $1.24 * *$ & $-3.91 * *$ & - & - & - & 94.39 & $58.34 * *$ & 1.08 & -2.03 & $4.18^{* *}$ & - & - & 97.34 \\
\hline L1 1 L4 & $61.90^{* *}$ & 0.39 & $-4.21^{* *}$ & - & - & - & 86.58 & $62.61 * *$ & $1.60^{*}$ & $-6.63^{* *}$ & - & - & - & 89.95 \\
\hline L1 $x$ L8 & $61.71 * *$ & 0.76 & $-2.83 * *$ & - & - & - & 91.24 & $62.29 * *$ & $1.92 * *$ & $-6.13^{* *}$ & - & - & - & 97.00 \\
\hline L2 $x$ L5 & $61.91 * *$ & -0.62 & $-3.73^{* *}$ & - & - & - & 81.08 & $62.61 * *$ & -0.39 & $-6.94 * *$ & - & - & - & 96.21 \\
\hline L3 $x$ L5 & $61.06^{* *}$ & -1.70 & $-3.11^{* *}$ & - & - & - & 86.87 & $61.06^{* *}$ & -1.06 & $-4.81^{* *}$ & - & - & - & 88.15 \\
\hline L4 x L5 & $62.28 * *$ & -0.53 & $-4.76^{* *}$ & - & - & - & 90.32 & $61.78 * *$ & -0.44 & $-4.95^{* *}$ & - & - & - & 81.72 \\
\hline L5 $x$ L8 & $61.88^{* *}$ & $1.13^{* *}$ & $-4.04 * *$ & - & - & - & 98.97 & $61.75^{* *}$ & 1.26 & $-4.95^{* *}$ & - & - & - & 93.80 \\
\hline L2 $\times$ L 7 & $61.99 * *$ & -0.55 & $-4.80^{* *}$ & - & - & - & 93.56 & $61.53 * *$ & 0.61 & $-4.24 * *$ & - & - & - & 82.15 \\
\hline L3 $\times$ L 7 & $61.00 * *$ & $-1.37 * *$ & $-4.65^{* *}$ & - & - & - & 94.98 & $61.25 * *$ & -0.36 & $-12.03 * *$ & - & - & $7.98 * *$ & 96.49 \\
\hline L4 $\times$ L7 & $62.28 * *$ & -0.25 & $-4.43^{* *}$ & - & - & - & 95.95 & $61.52 * *$ & -0.21 & $-5.44 * *$ & - & - & - & 84.24 \\
\hline L7 $x$ L8 & $61.65^{* *}$ & 0.62 & $-3.91 * *$ & - & - & - & 86.87 & $61.11^{* *}$ & 0.11 & $-4.20 * *$ & - & - & - & 97.17 \\
\hline L1 x L6 & $62.61 * *$ & $-1.05^{* *}$ & $-5.57 * *$ & - & - & - & 94.00 & $62.00 * *$ & 0.64 & $-3.29 * *$ & - & - & - & 67.53 \\
\hline L2 x L6 & $62.55^{* *}$ & $-0.96^{*}$ & $-7.31^{* *}$ & - & - & - & 94.89 & $57.23 * *$ & -0.65 & -1.34 & $5.06^{* *}$ & $-7.10 * *$ & - & 98.89 \\
\hline L3 3 L6 & $61.66^{* *}$ & $-2.13^{* *}$ & $-5.93 * *$ & - & - & - & 96.71 & $60.73 * *$ & -0.80 & $-5.37 * *$ & - & - & - & 89.65 \\
\hline L4 x L6 & $62.46^{* *}$ & $-1.23 * *$ & $-6.12 * *$ & - & - & - & 90.93 & $57.63 * *$ & 0.35 & -1.82 & $4.23 * *$ & $-8.70 * *$ & - & 99.99 \\
\hline L5 x L6 & $63.35^{* *}$ & -0.35 & $-9.53^{* *}$ & - & $4.10 * *$ & $4.78^{* *}$ & 98.55 & $61.75^{* *}$ & 0.50 & $-4.22 * *$ & - & - & - & 91.95 \\
\hline L6 $x$ L 7 & $51.59^{* *}$ & 0.45 & -1.67 & $3.67 * *$ & $4.90^{* *}$ & - & 99.40 & $61.29 * *$ & 0.75 & $-4.13^{* *}$ & - & - & - & 79.10 \\
\hline L6 $x$ L8 & $61.88^{* *}$ & $1.63^{* *}$ & $-4.84 * *$ & - & - & - & 91.12 & $61.26^{* *}$ & 0.46 & $-5.25^{* *}$ & - & - & - & 98.76 \\
\hline
\end{tabular}

$*, * *$ Significant at $\mathrm{p}=0.05$ and at $\mathrm{p}=0.01$, respectively.

${ }^{1}$ L1, L5 and L7 belong to G1 (tolerant), and L2, L3, L4 and L8 belong to G2 (sensitive), both groups derived from SA4 population. L6 was derived from SA5 population.

(1997) did not detect significant epistatic effects for prolificacy in an $\mathrm{F}_{2}$ population in non-acid soil.

The overall results of this research showed that the dominance effects play a more important role than additive effects and that the latter were more important than epistatic effects in both acid and non-acid soils. Similar results have been reported by Pandey et al. (2007). Epistatic effects were detected for all traits in both acid and non-acid soil environments. Epistatic effects have been considered as a result of unique combinations of genes in specific crosses, which may contribute to increased heterosis in elite single-crosses (Lamkey et al., 1995; Darrah and Hallauer, 1972). For example, Darrah and Hallauer (1972) reported a higher frequency of epistatic effects for yield in crosses between second-cycle inbreds than in crosses between first-cycle inbreds and attributed this to the effects of selection. However, our results showed no relationship between high-yielding single-crosses ( $\mathrm{F}_{1}$ generation) and epistasis because only one of the five high-yielding single-crosses presented significant epistatic effect $(a d)$ in acid soils and in non-acid soil none of them presented significant epistatic effects. Thus, epistatic effects were randomly distributed among the crosses.

Our results suggest that the inheritance of grain yield, plant height, mid-silk and prolificacy did not differ in acid and non-acid soils. Obviously, there are detrimental effects of the acid soils, mainly for grain yield, which cause the estimates of the genetic effects to be lower in acid than in non-acid soils. Thus, the accumulated knowledge on the inheritance of quantitative traits in non-acid fertile soils, summarized by Hallauer et al. (1988) and Hallauer and Miranda Filho (1988), can benefit maize breeding programs for acid soils environments. 


\section{Acknowledgments}

The authors are grateful to Dr. A.R. Hallauer and to Dr. R. Vencovsky for their constructive suggestions. Project \# 223-K8064 CIMMYT 5/94 "Adaptation of maize to aluminum toxic soils". Part of a thesis presented by J. C. Pérez Velásquez to the University of São Paulo, ESALQ/ USP, in partial fulfillment of the requirements for a doctoral degree in Agronomy.

\section{References}

Allen DM and Cady FB (1982) Analyzing Experimental Data by Regression. Lifetime Learning Publications, Belmont, 403 pp.

Bahia Filho AFC, Magnavaca R, Schaffert RE and Alves VMC (1997) Identification, utilization, and economic impact of maize germplasm tolerant to low levels of phosphorus and toxic levels of exchangeable aluminum in Brazilian soils. In: Moniz AC (ed) Plant Soil Interactions at Low pH: Sustainable Agriculture and Forestry Production. Sociedade Brasileira de Ciência do Solo, Campinas, pp 59-70.

Borrero JC, Pandey S, Ceballos H, Magnavaca R and Bahia Filho AFC (1995) Genetic variances for tolerance to soil acidity in a tropical maize population. Maydica 40:283-288.

Ceballos H, Pandey S, Knapp ER and Duque-Vargas J (1995) Progress from selection for tolerance to soil acidity in five tropical maize populations. In: Date RA (ed) Plant-Soil Interactions at Low pH: Principles and Management. Klüwer Academic Publishers, Dordrecht, pp.419-424.

Ceballos H, Pandey S, Narro L and Pérez JC (1998) Additive, dominant, and epistatic effects for maize grain yield in acid and non-acid soils. Theor Appl Genet 96:662-668.

Cockerham CC and Zeng ZB (1996) Design III with marker loci. Genetics 143:1437-1456.

Darrah LL and Hallauer AR (1972) Genetic effects estimated from generation means in four diallel sets of maize inbreds. Crop Sci 12:615-616.

Duque-Vargas J, Pandey S, Granados G, Ceballos H and Knapp ER (1994) Inheritance of tolerance to soil acidity in tropical maize. Crop Sci 34:50-54.

Eleutério A, Gama EEG and Morais AR (1988) Capacidade de combinação e heterose em híbridos intervarietais de milho adaptados às condições de Cerrado. Pesq Agropec Bras 23:247-253.

Galvão JD and Silva JC (1978) Herança da tolerância ao alumínio na variedade de milho Piranão. Rev Ceres 25:71-78.

Gamble EE (1962a) Gene effects in corn I. Separation and relative importance of gene effects for yield. Can J Plant Sci 42:339-348.

Gamble EE (1962b) Gene effects in corn II. Relative importance of gene effects for plant height and certain component attributes of yield. Can J Plant Sci 42:339-348.

Granados G, Pandey S and Ceballos H (1993) Response to selection for tolerance to acid soils in a tropical maize population. Crop Sci 33:936-940.

Hallauer AR and Miranda Filho JB (1988) Quantitative Genetics in Maize Breeding. Iowa State Univ. Press, Ames, 468 pp.
Hallauer AR, Russell WA and Lamkey KR (1988) Corn breeding. In: Sprague GF and Dudley JW (eds) Corn and Corn Improvement. Am Soc Agron, Madison, pp. 463-564.

Jinks JL, Perkins JM and Pooni HS (1973) The incidence of epistasis in normal and extreme environments. Heredity 31:263-269.

Lamkey KR, Schnicker BS and Melchinger AE (1995) Epistasis in an elite maize hybrid and choice of generation for inbred line development. Crop Sci 35:1272-1281.

Lima M, Furlani PR and Miranda Filho JB (1992) Divergent selection for aluminum tolerance in a maize population. Maydica 37:123-132.

Lopes MA, Magnavaca R, Bahia Filho AFC and Gama EEG (1987) Avaliação de populações de milho e seus cruzamentos para tolerância a toxidez de alumínio em solução nutritiva. Pesq Agropec Bras 22:257-263.

Magnavaca R, Gardner CO and Clark RB (1987a) Comparisons of maize populations for aluminum tolerance in nutrient solution. In: Gabelman HW and Loughman BC (eds) Genetic Aspects of Plant Mineral Nutrition. Martinus Nijhoff Publishers, Dordrecht, pp 189-199.

Magnavaca R, Gardner CO and Clark RB (1987b) Inheritance of aluminum tolerance in maize. In: Gabelman HW and Loughman BC (eds) Genetic Aspects of Plant Mineral Nutrition. Martinus Nijhoff Publishers, Dordrecht, pp 201-212.

Mather K and Jinks L (1982) Biometrical Genetics. Chapman and Hall, New York, 396 pp.

Moreno-Gonzalez J and Dudley JW (1981) Epistasis in related and unrelated maize hybrids determined by three methods. Crop Sci 21:644-651.

Narro L, Pérez JC, Pandey S, Crossa J, Salazar F, Arias M and Franco J (2000) Diallel and triallel analysis in an acid soil tolerant maize population. Maydica 45:301-308.

Naspolini Filho V, Bahia Filho AFC, Vianna RT, Gama EEG, Vasconcelos CA and Magnavaca R (1981) Comportamento de linhagens e híbridos simples de milho em solos sob vegetação de Cerrado. Ciên Cult 33:722-727.

Pandey S and Gardner CO (1992) Recurrent selection for population, variety and hybrid improvement in tropical maize. Adv Agron 48:1-87.

Pandey S, Ceballos H, Magnavaca R, Bahia Filho AFC, DuqueVargas J and Vinasco LE (1994) Genetics of tolerance to soil acidity in tropical maize. Crop Sci 34:1511-1514.

Pandey S, Ceballos H and Granados G (1995) Registration of four tropical maize populations with acid-soil tolerance. Crop Sci 35:1230-1231.

Pandey S, Narro L, Friesen DK and Waddington SR (2007) Breeding maize for tolerance to soil acidity. Plant Breed Rev 28:59-100.

Roy AK, Sharma A and Taludker G (1988) Some aspects of aluminum toxicity in plants. The Bot Review 54:145-147.

Salazar F, Pandey S, Narro L, Pérez JC, Ceballos H, Parentoni S and Bahia Filho AFC (1997) Diallel analysis of acid soil tolerant and intolerant tropical maize populations. Crop Sci 37:1457-1462.

Von Uexkull HR and Mutert E (1995) Global extent, development and economic impact of acid soils. In: Date RA (ed) Plant-Soil interaction at Low pH: Principles and Management. Klüwer Academic Publishers, Dordrecht, pp 5-19.

Wolf DP and Hallauer AR (1997) Triple testcross analysis to detect epistasis in maize. Crop Sci 37:763-770.

Senior Editor: Ernesto Paterniani 